\title{
Entandrophragma: taxonomy and ecology of a genus of African tree species with economic importance. A review
}

\author{
Emmanuel Kasongo Yakusu ${ }^{(1,2,3)}$, Franck S. Monthe ${ }^{(4)}$, Nils Bourland ${ }^{(3,5,6)}$, \\ Olivier J. Hardy ${ }^{(4)}$, Dominique Louppe ${ }^{(7)}$, Félicien Bola Mbele Lokanda ${ }^{(8)}$, \\ Wannes Hubau ${ }^{(2,3)}$, Jean-Marie Kahindo Muhongya ${ }^{(8)}$, Jan Van Den Bulcke ${ }^{(2)}$, \\ Joris Van Acker ${ }^{(2)}$, Hans Beeckman ${ }^{(3)}$
}

(1) Université de Kisangani. Faculté de Gestion des Ressources Naturelles Renouvelables. B.P. 2012. Avenue Kitima, 3. Kisangani (Democratic Republic of Congo).E-mail : emmakasongo1@yahoo.fr

${ }^{(2)}$ Ghent University. Faculty of Bioscience Engineering. Department of Environment UGent-Woodlab. Laboratory of Wood Technology. Coupure Links, 653. BE-9000 Ghent (Belgium).

(3) Royal Museum for Central Africa. Service of Wood Biology. Leuvensesteenweg, 13. BE-3080 Tervuren (Belgium).

(4) Université libre de Bruxelles. Faculté des Sciences. Évolution biologique et Écologie. CP 160/12. Avenue F. D. Roosevelt, 50. BE-1050 Brussels (Belgium).

${ }^{(5)}$ Centre de Recherche Forestière Internationale. Situ Gede Bogor Barat 16115 (Indonésie).

${ }^{(6)}$ Resources and Synergies Development. Noliktavu iela, 7. Dreilini, Stopinu novads. Riga 2130 (Lettonia).

(7) Centre de coopération Internationale en Recherche Agronomique pour le Développement (Cirad). Département forestier. Campus international de Baillarguet. TA 10/C 34398. FR-Montpellier Cedex 5 (France).

${ }^{(8)}$ Université de Kisangani. Faculté des Sciences. B.P. 2012. Avenue Kitima, 3. Kisangani (Democratic Republic of Congo).

This paper is the translation in English of the paper "Le genre Entandrophragma (Meliaceae) : taxonomie et écologie d'arbres africains d'intérêt économique (synthèse bibliographique)", Biotechnol. Agron. Soc. Environ., 2018, 22(2), 113-127.

This article is distributed under the terms and conditions of the CC-BY License (http://creativecommons.org/licenses/by/4.0)

Introduction. Entandrophragma tree species have been the subject of special attention by foresters and scientists for several decades. The purpose of this bibliographic review is to examine the current knowledge acquired on the taxonomy and ecology of this genus in order to identify new research priorities.

Literature. The genus Entandrophragma has exclusively African species (10 to 12) that are exploited for the quality of their wood. These species are widespread in the Guineo-Congolese region (6 species) and in the Zambezian and Afromontane regions ( 5 species). The genus is characterized by a taxonomic evolution that has resulted in an important synonymy of species names (36 to 37). Ecological studies have been carried out on some major commercial species (Entandrophragma angolense, Entandrophragma congoense, Entandrophragma candollei, Entandrophragma cylindricum, Entandrophragma palustre and Entandrophragma utile) in their phytogeographic zones, mainly in the Guineo-Congolese region.

Conclusions. Taxonomy and ecology of Entandrophragma tree species typically occurring in woodlands and savannas have been insufficiently studied in comparison with Entandrophragma species occurring in rainforests. Research needs to be developed for the improvement of taxonomic, genetic and ecological knowledge, with a view to formulating appropriate recommendations for the conservation and sustainable management of these species.

Keywords. Forest ecology, population genetic, natural range, taxonomy of tree species, tropical forests, Africa.

Le genre Entandrophragma (Meliaceae) : taxonomie et écologie d'arbres africains d'intérêt économique (synthèse bibliographique)

Introduction. Les espèces d'arbres du genre Entandrophragma font l'objet d'une attention toute particulière de la part des exploitants forestiers et des scientifiques depuis plusieurs décennies. Établir un bilan exhaustif actualisé des connaissances acquises sur leur taxonomie et leur écologie afin d'en dégager des pistes de nouvelles recherches est le but de cette synthèse bibliographique.

Littérature. Le genre Entandrophragma compte des espèces (10 à 12) exclusivement africaines et qui sont exploitées pour la qualité de leur bois. Ces espèces sont répandues dans la région guinéo-congolaise (6 espèces) et dans les régions zambézienne et afromontagnarde (5 espèces). Le genre est caractérisé par une évolution taxonomique qui s'est traduite par une importante synonymie des noms d'espèces (36 à 37). Des études écologiques un peu larges ont été réalisées sur quelques 
principales espèces commerciales (Entandrophragma angolense, Entandrophragma congoense, Entandrophragma candollei, Entandrophragma cylindricum, Entandrophragma palustre et Entandrophragma utile) dans leurs zones phytogéographiques comprises principalement dans la région guinéo-congolaise.

Conclusions. Les informations sur la taxonomie et l'écologie des espèces d'arbres d'Entandrophragma des forêts claires et des savanes sont insuffisantes comparativement à celles des forêts denses humides. Des travaux de recherches devraient être développés pour l'amélioration des connaissances taxonomiques, génétiques et la maitrise de leur écologie en vue de formuler des recommandations adéquates en matière de préservation et de gestion durable de ces espèces.

Mots-clés. Écologie forestière, génétique des populations, distribution géographique, taxonomie des essences forestières, forêt tropicale, Afrique.

\section{INTRODUCTION}

The genus Entandrophragma C.DC. comprises according to sources 10 to 12 tree species distributed exclusively in tropical Africa. Belonging to the tribe of Swietenieae A.Juss. and the family Meliaceae, it is related to the genera Lovoa Harms, Khaya A.Juss, Pseudocedrela Harms (Lemmens, 2008) and Cedrela P. Browne (Koenen et al., 2015).

Within the family Meliaceae, the genus Entandrophragma is the richest in valuable species exploited as timber in Africa (Tailfer, 1989). In addition to its economic importance, this genus is of scientific interest, especially taxonomically, given the multiplicity of genera to which Entandrophragma species were initially attached and the number of specific synonymies (36-37; Louis \& Fouarge, 1947; Hall, 2008; The Plant List, 2013).

Insufficient information on the ecology of commercial Entandrophragma species leads to a lack of knowledge of the basic parameters of their population dynamics and, consequently, to inadequate decision-making by forest managers (Doucet, 2003; FAO, 2011; Biwolé et al., 2012). Moreover, information on the geographical distribution, ecology, taxonomy, genetics and evolution of Entandrophragma species is still fragmentary.

The general objective of this study is to review the knowledge acquired on the taxonomy and ecology of all Entandrophragma species, with a special focus on the main species exploited in dense moist forests.

The specific objectives are as follows:

- to describe the evolution of their taxonomy and their ecological characteristics;

- to discuss aspects for which knowledge remains insufficient or imprecise in order to suggest avenues for future research in support of improving their sustainable management.

\section{TAXONOMY OF GENUS}

\subsection{History, synonymy and taxonomical subdivision}

Historical background. The genus name Entandrophragma was proposed in 1894 by Casimir de Candolle in his "Monographie des Méliacées". Its etymology alludes to the unique floral particularity of this genus in the Meliaceae family: the existence of a disc under the ovary and ten real "phragma" partitions which form cups at the base of the staminal tube (Tailfer, 1989). Similarities were made with the American genus Swietenia Jacq. in 1858 by Welwitsch, then with the Asian genus Chukrasia A.Juss. by de Candolle in 1894. The latter genus differs from Entandrophragma in the flowers, by a long and narrow staminal tube with no internal partition, and especially by the fruit, which is a multisperm erect capsule (Louis \& Fouarge, 1947).

Synonymy. The genus Entandrophragma is also characterized by an important evolution in the synonymy of the names of the species described by different authors, the census of which leads to a total of 36 to 37 species (Table 1). According to Louis \& Fouarge (1947), this abundant taxonomic synonymy may be due to the important economic interest of the genus. This interest may have led to renewed attention on the part of systematists who, as a result of the phenotypic variability within species, may have encouraged the sometimes abusive creation of species. Indeed, some of these species were described and named by different authors with insufficient knowledge of the scientific literature of the time. The gradual improvement of scientific knowledge has made it possible to group some of these species into a single species and thus eliminate these synonymies, which are generally old (Table 1). Thus, the Conservatoire and the Botanical Garden of the City of Geneva (CJBG, 2012) currently recognizes only 10 species (E.congoense [Pierre ex De Wild.] A.Chev. not included) in the entire African area (Table 1). Among the species now recognized E. angolense (Welw.) C.DC. has a very abundant synonymy, probably due to the relative polymorphism it displays like many large trees with a wide distribution. Relative confusion still persists to this day concerning the synonymy of E. angolense and E. congoense, supported by Louis \& Fouarge (1947) and more recently by Chevallier et al. (2010). On the other hand, Wilks \& Issembé (2000) and de Wilde (2015) recognize that E. angolense and E.congoense are distinct species. This distinction is also made by forest prospectors in Gabon and Cameroon by calling 
Table 1. Synonymy and subdivision of 10 Entandrophragma species recognized in the African Plant Database (Conservatoire et Jardin Botaniques de la Ville de Genève). Two additional species are mentionned in (CThe Plant List 2013 - Synonymie et subdivision de 10 espèces d'Entandrophragma reconnues dans la base de données des plantes d'Afrique (Conservatoire et Jardin Botaniques de la Ville de Genève). Deux espèces supplémentaires sont répertoriées dans la base de données CThe Plant List 2013.

\begin{tabular}{|c|c|c|}
\hline $\begin{array}{l}\text { Section } \\
\text { (Louis \& Fouarge, 1947) }\end{array}$ & $\begin{array}{l}\text { Specific names currently accepted } \\
\text { (www.villege.ch/musinfo/bd/cjb/africa/, } \\
\text { 07/03/2015) }\end{array}$ & $\begin{array}{l}\text { Synonyms according to Louis } \& \\
\text { Fouarge (1947) and www.villege.ch/ } \\
\text { musinfo/bd/cjb/africa/, (07/03/2015) }\end{array}$ \\
\hline Neoentandrophragma Harms & $\begin{array}{l}\text { E. utile (Dawe \& Sprague) Sprague } \\
\text { (TN: sipo) }\end{array}$ & $\begin{array}{l}\text { E. roburoides Vermoesen (1921) } \\
\text { E. thomasii Ledoux (1932) } \\
\text { E. macrocarpum A.Chev. (1909) } \\
\text { Pseudocedrela utilis Dawe \& Sprague } \\
\text { (1906) }\end{array}$ \\
\hline Pseudoentandrophragma Harms & $\begin{array}{l}\text { E. cylindricum (Sprague) Sprague } \\
\text { (TN: sapelli) }\end{array}$ & $\begin{array}{l}\text { E. lebrunii Staner (1930) } \\
\text { E. angolense Auct. Non C.DC. } \\
\text { E. tomentosum A.Chev. ex Hutch. \& } \\
\text { Dalziel (1928) } \\
\text { E. rufum A.Chev. (1909) }\end{array}$ \\
\hline \multirow[t]{2}{*}{ Choriandra Harms } & E. palustre Staner (TN: -) & $\begin{array}{l}\text { Heimodendon tisserantii Sillans } \\
\text { Heimodendron tisserantii Sillans (1953) }\end{array}$ \\
\hline & E. candollei Harms (TN: kossipo) & $\begin{array}{l}\text { E. choriandrum Harms } \\
\text { E. ferruginea A.Chev. }\end{array}$ \\
\hline \multirow[t]{3}{*}{ Euentandrophragma Harms } & $\begin{array}{l}\text { E. angolense (Welw.) C.DC. } \\
\text { (TN: white tiama) }\end{array}$ & $\begin{array}{l}\text { E. casimiriana De Wild. \& Th. Dur. } \\
\text { E. candolleanum De Wild. \& Th. Dur. } \\
\text { (1899) } \\
\text { E. gregoireianum Staner (1930) } \\
\text { E. congoense (De Wild.) A.Chev. (*) } \\
\text { E. platanoides Vermoensen (1921) } \\
\text { E. leplaei Vermoense (1921) } \\
\text { E. congoensis (Pierre ex De Wild.) } \\
\text { A.Chev. } \\
\text { E. macrophyllum A.Chev. (1909) } \\
\text { E. pierrei A.Chev. (1909) (*) } \\
\text { E. cylindricum Auct. Non (Sprague) } \\
\text { Sprague } \\
\text { E. rederi Harms (1910) } \\
\text { E. septentrionale A.Chev. (1909) } \\
\text { Swietenia angolensis Welw. (1859) } \\
\text { Leioptux congensis } \text { Pierre ex De Wild. }\end{array}$ \\
\hline & $\begin{array}{l}\text { E. excelsum (Dawe et Sprague) Sprague } \\
\text { (TN: mountain mahogany) }\end{array}$ & $\begin{array}{l}\text { Pseudocedrela excelsa Dawe \& Sprague } \\
\text { E. speciosum Harms } \\
\text { E. gillardini Ledoux } \\
\text { E. stolzii Harms (1917) } \\
\text { E. deiningeri Harms (1917) }\end{array}$ \\
\hline & $\begin{array}{l}\text { E. delevoyi De Wild } \\
\text { (TN: -) }\end{array}$ & E. lucens Hoyle (1932) \\
\hline \multirow[t]{3}{*}{ Wulfhorstia (C.DC.) Sprague } & $\begin{array}{l}\text { E. spicatum (C.DC.) Sprague } \\
\text { (TN: mutaco) }\end{array}$ & $\begin{array}{l}\text { Wulfhorstia spicata } \text { C.DC. (1900) } \\
\text { E. ekebergioides (Harms) Sprague } \\
\text { Wulfhorstia ekebergioides Harms (1903) }\end{array}$ \\
\hline & E. caudatum Sprague (TN: -) & Pseudocedrela caudata Sprague (1908) \\
\hline & E. bussei Harms (TN: -) & - \\
\hline
\end{tabular}

-: no information - pas d'information; TN: trade name - nom commercial; (*): species accepted by CThe Plant List 2013 - espèces acceptées par CThe Plant List 2013, http://www.theplantlist.org/tpl1.1/record/kew-2789562, (20/12/2016); http://www.theplantlist.org/ tpl1.1/record/kew-2789547, (20/12/0216). 
them "white tiama" (E. angolense: greyish-white to grey-brown trunk and pink edge with whitish stripes) and "black tiama" (E.congoense: brownish-blackish trunk and fairly dark reddish-pink edge; Meunier et al., 2015) respectively. For the rest of this study, we will recognize $E$. congoense and $E$. angolense as two species in their own right according to the "Flore du Gabon" (de Wilde, 2015). Thus, we consider that there are 11 species of Entandrophragma and not 10. Furthermore, studies using more advanced molecular genetic approaches and coupled with other botanical criteria notably leaflet symmetry and the number of secondary veins, would be necessary to remove some uncertainties regarding the difference between the two tiamas.

Subdivision. With the exception of E.congoense, for which doubts remain, Entandrophragma species were grouped into five sections (Table 1) by Louis \& Fouarge (1947). This subdivision is based on fertile characters including the existence of the disc on the ovary, the nature of the ten partitions delimiting the ten cups at the base of the staminal tube and the shape of the capsule. The usefulness of such a subdivision lies in the interspecific links it highlights. However, the study of other characteristics, particularly ecological, anatomical and genetic, would allow a better description of the links/differences between Entandrophragma species.

\subsection{Botanical identification key for Entandrophragma species}

Different keys for botanical identification of Entandrophragma species have been proposed (e.g., Staner, 1943; Wilks \& Issembé, 2000; de Wilde, 2015). These keys are based respectively on the description of vegetative and reproductive characteristics (flowers and fruits). However, no flora or field guide proposes an identification key integrating all the Entandrophragma species, including E. spicatum (C.DC.) Sprague, E. caudatum (Sprague) Sprague and E.bussei Harms, which are nevertheless partially described. The present review proposes a single key based on the combination of these two main characters (Box 1). The identification of large, fertile Entandrophragma seems fairly easy, but flowers are not always available.

Table 2 presents the vegetative criteria for identifying Entandrophragma in dense moist forests, including young trees that are not yet fruit bearing (e.g. Wilks \& Issembé, 2000; Meunier et al., 2015).

\section{GEOGRAPHICAL DISTRIBUTION}

The genus Entandrophragma is exclusively African. The limits of the climatically homogeneous geographical entities generally used (region, sub-region, domain, etc.) by each author (e.g., Louis \& Fouarge, 1947; White, 1986) depend on the degree (spatial dimension) and nature (temporal dimension) of the distributions observed on the basis of available floristic and ecological data. Louis \& Fouarge (1947) use the term "domain" (e.g., Zambezian, oriental, etc.) to locate the distribution area of Entandrophragma, whereas White (1986) prefers the term "region", or "sub-region" according to Sépulchre et al., 2008. The present review prefers White's (1986) concepts since they are the most commonly used and are derived from the classic process of endemism in species conservation that led to the production of the map of the main phytocories of Africa and Madagascar.

The genus Entandrophragma has two main geographical distributions (Figure 1).

The first group is composed of six species with very wide Guineo-Congolese distributions: E. angolense (white tiama), E. congoense (black tiama), E. candollei (kosipo), E.cylindricum (sapelli), E.palustre Staner and E. utile (sipo). Not including E.palustre which is restricted to swamp forests in the Democratic Republic of Congo and the Republic of Congo and probably other parts of Central Africa (Lemmens, 2008), the other species grow in evergreen and semi-deciduous dense rainforests (Meunier et al., 2015) where E. cylindricum (Sprague) Sprague and E. angolense are locally more abundant than E.candolei Harms and E. utile (Dawe \& Sprague) Sprague (Doumenge et al., 2010). These species extend in a wide band north and south of the equator from the Atlantic coast through the Congo Basin to the western slope of the Kivu Ridge in the east (White, 1986). The one with the most extensive distribution among these four species is E. angolense (Figure 1). It is certainly confused with its synonym (E. congoense) by the CJBG.

The second group comprises five species with "Zambezian" and "Afromontane" distributions (E.bussei, E.caudatum, E. delevoyi, E. spicatum and E. excelsum) (Louis \& Fouarge, 1947; White, 1986; Malaisse, 1993; Lemmens, 2008). Entandrophragma excelsum (Dawe \& Sprague) Sprague is a species with both a "Zambezian" and "Afromontane" distribution where it is restricted to mountain forests (Louis \& Fouarge, 1947) and occurs in eastern DRC, Rwanda, Burundi, Uganda, Tanzania, Malawi and Zambia (Lemmens, 2008). Entandrophragma excelsum (Dawe \& Sprague) Sprague is a species with both a "Zambezian" and "Afromontane" distribution where it is restricted to mountain forests (Louis \& Fouarge, 1947) and occurs in eastern DRC, Rwanda, Burundi, Uganda, Tanzania, Malawi and Zambia (Lemmens, 2008), E. caudatum, E. delevoyi and E. spicatum, known as "Zambezian", are found in dry open or evergreen forests (Louis \& Fouarge, 1947; Lemmens, 2008). Only E. delevoyi (with Zambezian and Afromontane distribution) is 
1. Terminal bud glabrous or glabrous; petals glabrous on both sides; anthers exserted, elliptical, rounded at the top:

2. Leaflets hairless, except midrib on underside; petioles 1-6 mm; staminal tube with entire margins,

not thickened E. angolense

3. Midrib underneath glabrous on the flanks; network of protruding ribs; sometimes with domatia

in the armpit of the ribs; staminal tube 2-3 mm long

1. Terminal bud tomentose or puberulent; petals at least hairy or puberulent on the outside; anthers exserted

or included, elliptical or lanceolate:

4. Species of eastern mountain forests

E. excelsum

4. Hygrophilous forest species:

5. Leaflets hairless or rarely with fine puberulence on the veins on the face underside without cryptic pubescent domatia; petals refracted with hairy anthesis on both sides:

6. Stalks 1-5 mm long, pubescent; leaflets 10-18, with 15-22 pairs of lateral veins; petals

oblanceolate, narrow at base; anthers exserted, elliptic, rounded at apex E. candollei

6. Stalks 7-10 mm long, hairless; leaflets 6-10 in number, with $10-13$ pairs of lateral veins; petals oval-oblong, unshrunken at the base; anthers included, triangular and acute at the apex; swamp forest species E. palustre

5. Leaflets with pubescent cryptic domatia in the armpit of the lateral veins on the underside:

7. Leaflets with 10-16 very prominent lateral pairs on the underside, not anastomosing in an arc towards the edge; ovary with 6-8 ovules in two sets E. utile

7. Leaflets with 6-9 pairs of lateral ribs not very prominent on the underside, anastomosing in an arc towards the edge; exserted triangular anthers ending in a small point at the apex

8. Endemic to Tanzania, found in deciduous thickets, open forest and shrubby savannah:

9. Leaflets oval, asymmetrical, slightly pubescent underneaths E. congoense

. Species of dry open or evergreen:

10. Leaflets hairless; stalks $15-35 \mathrm{~mm}$; staminal tube with lobed edges, thickened at the top

11. Leaflets in 3-7 pairs, up to $110 \times 70 \mathrm{~mm}$, broadly oblong or obovate-oblong; lower surface

densely puberulent, vein forming an apparent network

12. Fruit: a woody capsule, up to $15 \mathrm{~cm}$ long, dividing into 5 valves, which bend backwards showing winged seeds attached to a central column E. cylindricum

13. Fruits with basilar dehiscence:
14 . Very thin valves, $1-1.5 \mathrm{~mm}$ thick, straw yellow columella marbled with dark brown spots .E. bussei 14. 4-5 mm valves; unmarbled columella:

15. Mahogany brown columella; $1.5 \mathrm{~cm}$ square seeds ....

15. Chocolate-brown columbine; ovoid seeds $2.5 \mathrm{~cm}$ long and $1.5 \mathrm{~cm}$ wide E. delevoyi

Fruits with apical dehiscence:

16. Fruit claviform or ellipsoid, $18-28 \mathrm{~cm}$ long, 5-7 cm wide; columella not specified E. spicatum

16. Fruits not claviform, not exceeding $5 \mathrm{~cm}$ wide; columella with hail stipe or $5 \mathrm{~cm}$ not stipulated not bearing at the base the remains of the valves:

17. Fruit not specified at the base, $7-15 \mathrm{~cm}$ long and $2.5-3 \mathrm{~cm}$ wide; cylindrical columella with winged edges on $1 / 2$ length

17. Fruits stipulated at the base:

18. Fruits $17-23 \mathrm{~cm}$ long; columella to stipe $3-5 \mathrm{~cm}$ long

18. Fruit $22-27 \mathrm{~cm}$ long; $8-10 \mathrm{~mm}$ long columella with stipe E. caudatum E. delevoyi E. angolense E. excelsum ..E. utile

Box 1. Global simple botanical identification key of the Entandrophragma species based on the vegetative and reproductive traits (flowers and fruits) (Staner, 1943; Roux, 2003; Lemmens, 2008; de Wilde et al., 2015; Burrows et al., 2017) - Clé simple et globale d'identification botanique d'espèces d'Entandrophragma basée sur les caractères végétatifs et reproducteurs (fleurs et fruits) (adapté d'après Staner, 1943 ; Roux, 2003 ; Lemmens, 2008 ; de Wilde et al., 2015 ; Burrows et al., 2017 ).

mainly characteristic of dense dry forests (Dikumbwa, 1990; Malaisse, 1993; Malaisse et al., 2000). Figure 1 shows that its distribution is wider in DRC and Zambia, and restricted in Tanzania. In contrast, E.caudatum is distributed in southern Zambia and Malawi, northeastern South Africa, Zimbabwe, Mozambique and Botswana (Burrows et al., 2017), while E. spicatum is confined to southern Angola and northern Namibia (Figure 1). In addition, E. bussei (Afromontane distribution) is endemic to Tanzania where it occurs in deciduous thickets, open forest and shrubby savannah (Lemmens, 2008).

\section{PHYLOGENY AND GENETICS}

\subsection{Phylogeny}

For more than a decade, numerous molecular studies have clarified phylogenetic relationships within the 
Table 2. Botanical differentiation of main Entandrophragma rainforest species in Africa (adapted from Wilks \& Issembé, 2000; Meunier et al., 2015) - Différenciation botanique des principales espèces d'Entandrophragma des forêts denses humides en Afrique (adapté de Wilks \& Issembé, 2000 ; Meunier et al., 2015).

\begin{tabular}{|c|c|c|c|c|c|}
\hline $\begin{array}{l}\text { Distinctive } \\
\text { features }\end{array}$ & E. angolense & E. congoense & E. candollei & E.cylindricum & E.utile \\
\hline Tree & $\begin{array}{l}\text { up to } 50 \mathrm{~m} \text { high } \\
\text { and } 1.5 \mathrm{~m} \text { in } \\
\text { diameter, with } \\
\text { buttresses or } \\
\text { wheelbases at the } \\
\text { base }\end{array}$ & $\begin{array}{l}\text { cylindrical or with } \\
\text { wheelbases }\end{array}$ & $\begin{array}{l}\text { up to } 60 \mathrm{~m} \text { high and } \\
3 \mathrm{~m} \text { in diameter, } \\
\text { with a powerful } \\
\text { crown with large, } \\
\text { sinuous branches } \\
\text { and rounded } \\
\text { buttresses or } \\
\text { wheelbases that } \\
\text { often extend far } \\
\text { from the tree }\end{array}$ & $\begin{array}{l}\text { up to } 60 \mathrm{~m} \text { high } \\
\text { and more than } 2 \mathrm{~m} \\
\text { in diameter, with } \\
\text { rounded tops. At } \\
\text { the base, it has } \\
\text { wheelbases or } \\
\text { buttresses that are } \\
\text { sometimes highly } \\
\text { developed }\end{array}$ & $\begin{array}{l}\text { which can exceed } \\
60 \mathrm{~m} \text { in height and } \\
2 \mathrm{~m} \text { in diameter, } \\
\text { with a powerful } \\
\text { hemispherical } \\
\text { top. It is equipped } \\
\text { with wheelbases } \\
\text { or buttresses at the } \\
\text { base }\end{array}$ \\
\hline Trunk & $\begin{array}{l}\text { straight and } \\
\text { smooth cylindrical } \\
\text { to scaly, is } \\
\text { often marked } \\
\text { with irregular } \\
\text { depressions and } \\
\text { lenticels }\end{array}$ & $\begin{array}{l}\text { darker trunk with } \\
\text { vertical cracks and } \\
\text { elongated scales, } \\
\text { normally without } \\
\text { buttresses, a more } \\
\text { cylindrical base }\end{array}$ & $\begin{array}{l}\text { straight, smooth in } \\
\text { young trees, and } \\
\text { marked with many } \\
\text { deep depressions } \\
\text { giving a pitted } \\
\text { appearance, with } \\
\text { scales, sinuous } \\
\text { ridges and scars }\end{array}$ & $\begin{array}{l}\text { straight, grey to } \\
\text { brown, is almost } \\
\text { smooth in young } \\
\text { trees. It is then } \\
\text { covered with } \\
\text { scales, lenticels } \\
\text { and numerous } \\
\text { depressions in } \\
\text { very old trees, } \\
\text { giving it a prickly } \\
\text { appearance }\end{array}$ & $\begin{array}{l}\text { straight, silver-grey } \\
\text { to yellow-grey, } \\
\text { marked with } \\
\text { vertical cracks, } \\
\text { elongated scales } \\
\text { and lenticels }\end{array}$ \\
\hline Slice & $\begin{array}{l}\text { pink with whitish } \\
\text { stripes, it gives off } \\
\text { a very slight scent } \\
\text { of perfume }\end{array}$ & $\begin{array}{l}\text { pink-red, finely } \\
\text { fibrous, turning } \\
\text { brown, brittle, } \mathrm{E} \\
10-30 \mathrm{~mm} \\
\text { whitish to orange } \\
\text { inner layer }\end{array}$ & $\begin{array}{l}\text { pinkish-red to } \\
\text { whitish with } \\
\text { orange-yellow } \\
\text { granules. } \\
\text { Sometimes } \\
\text { gum-like lumps } \\
\text { are found on old } \\
\text { wounds }\end{array}$ & $\begin{array}{l}\text { pinkish-brown } \\
\text { and turning very } \\
\text { quickly to brown, } \\
\text { it has a very strong } \\
\text { fragrant smell }\end{array}$ & $\begin{array}{l}\text { pinkish-red, } \\
\text { sometimes with } \\
\text { white stripes, is } \\
\text { not very fragrant. } \\
\text { There is a whitish } \\
\text { film between the } \\
\text { dead and living } \\
\text { bark, and the } \\
\text { whitish inner layer } \\
\text { slowly turns brown }\end{array}$ \\
\hline Leafs & $\begin{array}{l}\text { grouped together } \\
\text { at the end of the } \\
\text { branches, are } \\
\text { composed of and } \\
\text { provided with } 4 \text { to } \\
9 \text { pairs of almost } \\
\text { opposite wide } \\
\text { leaflets, whose } \\
\text { acumen has folded } \\
\text { edges }\end{array}$ & $\begin{array}{l}\text { acumen often } \\
\text { "spoon-shaped" } \\
\text { (edge folded } \\
\text { up in the shape } \\
\text { of a spoon), } 8 \\
\text { to } 18 \text { pairs of } \\
\text { lateral ribs, more } \\
\text { elongated shape } \\
\text { than the white } \\
\text { tiama, } \mathrm{L} 7-15 \mathrm{~cm} \\
\text { rachis at } 8 \text { - the } \\
\text { pair of opposite } \\
\text { leaflets or nearly } \\
\text { so }\end{array}$ & $\begin{array}{l}\text { grouped together } \\
\text { at the end of the } \\
\text { branches, are } \\
\text { composed and } \\
\text { provided with } \\
5 \text { to } 9 \text { pairs of } \\
\text { leaflets with a } \\
\text { wavy surface, } \\
\text { and traversed by } \\
\text { numerous lateral } \\
\text { ribs (between } 15 \\
\text { and } 25 \text { pairs) }\end{array}$ & $\begin{array}{l}\text { grouped together } \\
\text { at the end of } \\
\text { the branches, } \\
\text { composed and } \\
\text { provided with } \\
6 \text { to } 10 \text { pairs of } \\
\text { leaflets, opposite or } \\
\text { alternating. They } \\
\text { are asymmetrical, } \\
\text { marked by a } \\
\text { network of } \\
\text { protruding ribs on } \\
\text { both sides, with the } \\
\text { upper side glossy } \\
\text { when dry, and } \\
\text { sometimes with } \\
\text { tufts of hair at the } \\
\text { base of the ribs }\end{array}$ & $\begin{array}{l}\text { composed of } \\
6 \text { to } 12 \text { pairs } \\
\text { of elongated, } \\
\text { asymmetrical } \\
\text { leaflets with } \\
\text { tufts of hair in } \\
\text { the armpit of the } \\
\text { lateral ribs, the } \\
\text { latter also being } \\
\text { more or less hairy }\end{array}$ \\
\hline
\end{tabular}


Table 2 (continued). Botanical differentiation of main Entandrophragma rainforest species in Africa (adapted from Wilks \& Issembé, 2000; Meunier et al., 2015) - Différenciation botanique des principales espèces d'Entandrophragma des forêts denses humides en Afrique (adapté de Wilks \& Issembé, 2000 ; Meunier et al., 2015).

\begin{tabular}{|c|c|c|c|c|c|}
\hline $\begin{array}{l}\text { Distinctive } \\
\text { features }\end{array}$ & E. angolense & E. congoense & E. candollei & E.cylindricum & E.utile \\
\hline Flower & greenish and small & - & green-yellow & $\begin{array}{l}\text { pale green and } \\
\text { small size }\end{array}$ & yellowish green \\
\hline Fruit & $\begin{array}{l}\text { large, elongated } \\
\text { capsules } \\
\text { reminiscent of } \\
\text { large cigars (up to } \\
22 \times 5 \mathrm{~cm} \text { ), with } \\
5 \text { woody valves } \\
\text { covered with } \\
\text { lenticels, which } \\
\text { open at the base } \\
\text { and remain fixed at } \\
\text { the top }\end{array}$ & $\begin{array}{l}\text { blackish fruits that } \\
\text { open late, they are } \\
\text { often found whole } \\
\text { on the ground }\end{array}$ & $\begin{array}{l}\text { elongated } \\
\text { brown capsules } \\
\text { reminiscent of large } \\
\text { cigars (up to } 23 \mathrm{x} \\
5 \mathrm{~cm} \text { ), sometimes } \\
\text { with lenticels, with } \\
5 \text { woody valves that } \\
\text { open from the top }\end{array}$ & $\begin{array}{l}\text { black on the } \\
\text { ground, are } \\
\text { elongated capsules } \\
\text { that look like } \\
\text { big cigars (up to } \\
22 \times 4 \mathrm{~cm} \text { ), with } \\
5 \text { valves opening } \\
\text { from the top and a } \\
\text { relatively smooth } \\
\text { surface }\end{array}$ & $\begin{array}{l}\text { large capsules } \\
\text { (up to } 28 \times 7 \mathrm{~cm} \text { ), } \\
\text { with very thick } \\
\text { valves, with a very } \\
\text { warty black-brown } \\
\text { surface spreading } \\
\text { out from the top } \\
\text { and remaining } \\
\text { fixed at the base }\end{array}$ \\
\hline Seed & $\begin{array}{l}\text { flattened and } \\
\text { winged }\end{array}$ & winged & $\begin{array}{l}\text { flattened and } \\
\text { winged }\end{array}$ & & $\begin{array}{l}\text { flat with a long } \\
\text { wing }\end{array}$ \\
\hline
\end{tabular}

«- : : no information - pas d'information.

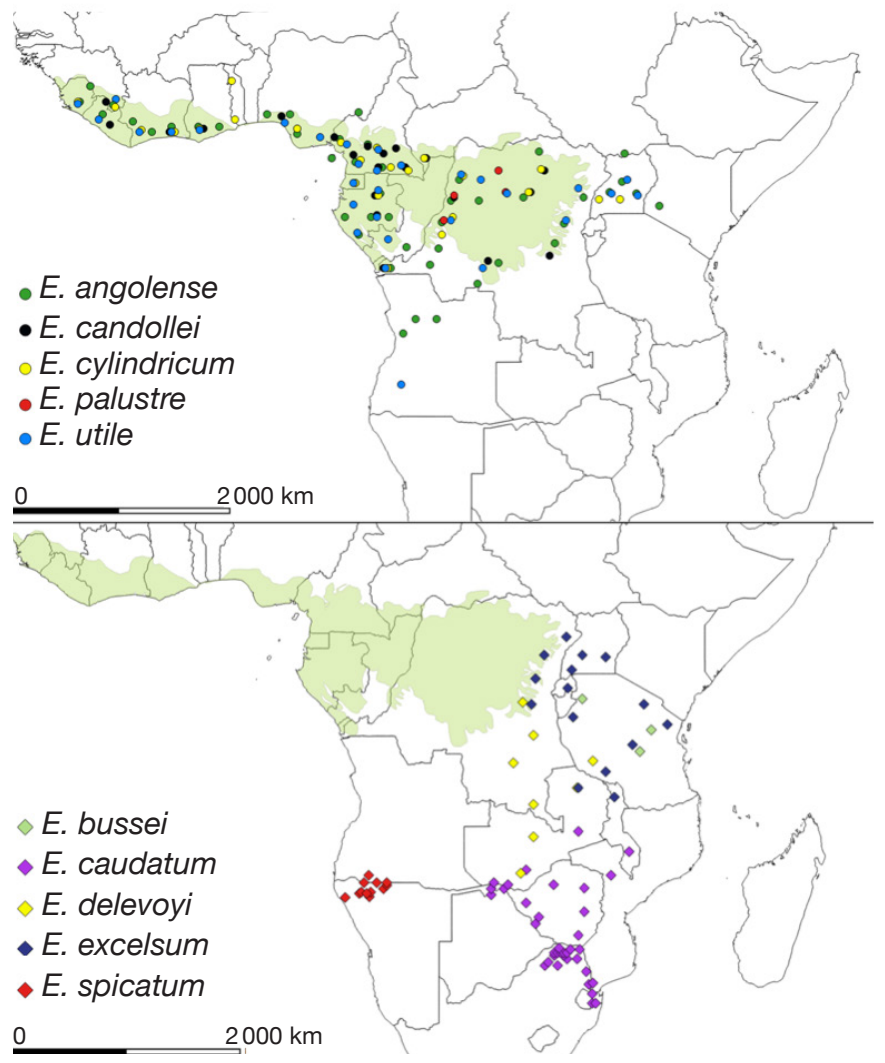

Figure 1. Geographical distribution of species of the genus Entandrophragma (map adapted from the database of the Conservatoire et Jardin botaniques de la Ville de Genève), which assimilates E. congoense to E. angolense - Répartition géographique des espèces $d u$ genre Entandrophragma (carte adaptée d'après la base de données des Conservatoire et Jardin Botaniques de la ville de Genève), qui assimile $\mathrm{E}$. congoense à E. angolense. family Meliaceae (Muellner et al., 2006; Muellner et al., 2009; Pennington et al., 2010; Muellner, 2011). Taxonomic revisions have been carried out, particularly for the genera Carapa Aubl., Cedrela and Leplaea (ex-Guarea) (Kenfack, 2011; Muellner et al., 2011). According to a recent phylogenetic study on Meliaceae, the genus Entandrophragma is considered to be close to the genus Cedrela from which it diverged during the Oligocene nearly 30 million years ago (Koenen et al., 2015). Despite these studies, the phylogenetic relationships and the origin of the diversification of species of the Entandrophragma genus are still unknown.

\subsection{Number of chromosomes and genetic markers}

The level of ploidy is fairly homogeneous within the genus Entandrophragma $(2 \mathrm{n}=36)$, although Mangenot \& Mangenot (1962) report a duplication of the level of ploidy in E. angolense, E. cylindricum, and E. utile $(2 \mathrm{n}=36$ or 72$)$. However, the existence of polyploid cytotypes has not been confirmed in E. cylindricum by the use of microsatellite markers since their development (Garcia et al., 2004). These genetic markers have opened the way for various studies on the reproductive system and gene dispersal in E. cylindricum (Lourmas et al., 2007; Monthe et al., 2017a), as well as on the identification of exploited feet in order to control their trade (Jolivet \& Degen, 2012). In particular, they have demonstrated that E. cylindricum is mainly allogamous and that pollen and seeds are on average dispersed at more than $600 \mathrm{~m}$ (Lourmas et al., 2007; Monthe et al., 2017a). The recent development 
of microsatellite markers for other Entandrophragma species (e.g., E. candollei and E. utile) (Monthe et al., $2017 b$ ) will most probably improve genetic knowledge of these taxa (e.g., analysis of the impact of exploitation on populations sensu Lourmas et al., 2007).

\section{ECOLOGY AND SILVICULTURE}

\subsection{Climatic niches, edaphic preferences and habitat}

Climatic niches. No global analysis has ever been carried out on the climatic niches of Entandrophragma over their entire range (Doumenge et al., 2010). Using information from herbarium specimens, forest inventories and other field surveys, Doumenge et al. (2010) proposed a climate niche modelling method which they applied to the four most exploited GuineanCongolese Entandrophragma species: E. angolense, E. candollei, E. cylindricum and E. utile. Apart from E. palustre, which prefers the wettest areas of the Congolese basin, this approach shows that species from dense humid forests seem to be more present in conditions of intermediate humidity, avoiding the most humid climates. A second group consists of species from "drier environments" (E. bussei, E. caudatum, E. delevoyi and E.spicatum). These acclimatise best in dry areas and show a clear separation from E. excelsum, which is characterized by high altitude climatic preferences, generally between 1,300 $\mathrm{m}$ and 2,100 m (Louis \& Fouarge, 1947; Lemmens, 2008).

Studies on the characterization of the climatic niches of Entandrophragma species remain insufficient and need to be regularly extended to take into account recent and future climate changes over their entire range.

Edaphic preferences and habitat. The habitats of the different species of Entandrophragma are distinguished by the physico-chemical properties of the soil. According to Hall et al. (2004), in the forests of southwestern Central African Republic (CAR), the presence of the five main Entandrophragma species (E.angolense, E.congoense, E.candollei, E. cylindricum and E. utile) in dense moist forests is correlated with the chemical composition of the soil. For example, only E. candollei tolerates very low fertility soils. Entandrophragma angolense and E. cylindricum are characteristic of soils with atypical $\mathrm{pH}$, whereas E.candollei is limited to particularly acidic soils. These analyses should be extended to other species of the genus and to other regions where several species coexist.

In addition, arbuscular and vesicular mycorrhizal associations have been recorded in the main
Entandrophragma species exploited by local forestry companies (Onguene \& Kuyper, 2001). Mycorrhizal inoculation therefore seems to favor the establishment of E. utile seedlings (Mujuni, 2008).

\subsection{Temperament and silviculture}

Temperament. The tolerance to shade in the juvenile stage of the most exploited Entandrophragma species in dense moist forests (sapelli, sipo, kosipo and white tiama) has been described in different ways according to the authors. These species have been described as sciaphiles (Louis \& Fouarge, 1947), shade-tolerant (Hall et al., 2003) or semi-heliophilic (Meunier et al., 2015; Doucet et al., 2016). Although a consensus has emerged from this work in favor of a certain shade tolerance (the semi-heliophilic temperament of these species is currently accepted), there are nevertheless nuances between species (kosipo, sipo, sapelli and white tiama) established by some authors. These nuances in light requirements can also be verified by a more detailed study of woody characteristics by quantifying the diameters of the vessels from pith to bark of the wood of the respective species (Beeckman, 2016). On the other hand, for species of the genus other than those exploited in dense moist forests (E. bussei, E. caudatum, E. delevoyi, E. excelsum and E. spicatum), temperament is less well known.

Silviculture. Insufficient knowledge of the temperament of each Entandrophragma species also hinders the implementation of silvicultural techniques, for example to optimize reforestation. Indeed, experiments conducted by Hall (2008) in CAR and by Doucet et al. (2016) in Cameroon show that silvicultural techniques used for regeneration of Entandrophragma species are confronted with high mortality rates. Several silvicultural techniques, notably the natural regeneration method by enrichment and single shelter-wood cutting, the layered method and the enrichment method by direct sowing, applied for the renewal of Entandrophragma have not given very satisfactory results. Other techniques to improve their regeneration have been tested, such as the creation of small intermediate-sized gaps in logged forests and the supply of seeds to obtain better regeneration (Hall et al., 2003; Makana \& Thomas, 2004). Nevertheless, the relevance of these regeneration methods is being questioned by new studies whose results have not been satisfactory with these species (Fayolle et al., 2015; Doucet et al., 2016). All the sapelli observed in Cameroon by Owona Ndongo et al. (2009) presented numerous difficulties due to insect bites during juvenile growth, which would explain in particular their initial delay in growth. According to Eckebil et al. (2017), silviculture of E. cylindricum is only just beginning. 
Indeed, there is still a need for further silvicultural research on all Entandrophragma species throughout their range.

\subsection{Phenology and fruiting diameter}

Phenology. In general, studies on phenology have only been carried out on some Entandrophragma species (E.angolense, E.candollei, E.cylindricum, E.utile, E. delevoyi and E.caudatum) and more rarely and insufficiently on others (e.g., E.bussei, E. excelsum and E. spicatum).

Indeed, Louis \& Fouarge (1947) precise that in the DRC the Entandrophragma of dense humid forests (E.angolense, E.candollei, E.cylindricum, $E$. palustre and $E$. utile) are recognized as deciducifolia with the exception of E. palustre which is evergreen. The period of leaf removal corresponds approximately to the season of reduced rainfall (beginning of the long dry season). In the forests of West Africa, some phenological studies (Taylor, 1960; Voorhoeve, 1965; Poorter et al., 2004) describe the flowering and fruiting periods of the four main and most exploited species (kosipo, sipo, sapelli and white tiama) (Table 3).

The phenology of Entandrophragma varies a priori according to regions. In Central Africa, and specifically in the Republic of Congo (RC), Gillet et al. (2008) report that the leaf capital of $E$. candolle $i$ is reconstituted from September to October after caterpillar attack; flowers are present in December and fruiting takes place in March-April. In E. cylindricum (semi-deciduous), leaf renewal takes place in September after the attack of edible caterpillars "Imbrasia oyemensis" (Gillet et al., 2008) in August (Eckebil et al., 2017).

In E. delovoyi from the dry dense forests of DRC, maximum leaf fall is observed in September and combined fruit and seed fall is generally observed in January (Dikumbwa, 1990). It is also noted that the flowering period in E. caudatum is from September to October (Burrows et al., 2017).

Fruiting diameter. Quantitative data on minimum fruiting diameter (MFD) and regular fruiting diameter
(RFD) of Entandrophragma species in moist dense forests (Table 4) are still fragmentary. The MFD is considered to be the threshold at which the first flowering and fruiting starts are observed, which nevertheless result in low diaspora production. This diameter is also called the minimum fertility diameter. The RFD is that from which efficient and regular fructification is observed (Sépulchre et al., 2008). The latter diameter is above all a tool to help determine the minimum exploitable diameter of a species (Menga et al., 2012) because it is indispensable that trees are only exploited (if they are well conformed) if they largely exceed this diameter in order to ensure their regeneration and the sustainability of the species. Although the MFD is determined for some of these species, the RFD is still generally unknown (Durrieu de Madron \& Daumerie, 2004; Menga et al., 2012). Minimum legal logging diameters (MLDs) are a fundamental tool for sustainable management that takes into account the diametric structure of tree populations and the need to preserve from felling the fraction of seed trees that must ensure regeneration (Durrieu de Madron et al., 1998; Eckebil et al., 2017). The minimum legal logging (MLD) is then compared to the MFD and RFD when it comes to the rational management of populations of one or more species. Such comparisons should thus be used to revise these exploitation thresholds if necessary.

Table 4 shows us that the MLDs for the main commercial Entandrophragma species have been established on an empirical basis by national forest administrations because they vary greatly from one country to another: for example, between 60 and $110 \mathrm{~cm}$ for E.candolei between Côte d'Ivoire and Ghana.

\subsection{Dissemination, natural regeneration and population structure}

Dissemination. Entandrophragma species are all anemochores (Louis \& Fouarge, 1947; Medjibe \& Hall, 2002; Poorter et al., 2004; Doucet et al., 2016). The capsular fruits of these species show septic dehiscence

Table 3. Phenology of Entandrophragma species in West Africa (mainly in Côte d'Ivoire, Liberia and Ghana) - Phénologie des espèces d'Entandrophragma en Afrique de l'ouest (principalement en Côte d'Ivoire, Libéria et Ghana).

\begin{tabular}{|c|c|c|c|c|c|}
\hline Species & Trade name & Foliage & Flowering period & Fruiting period & References \\
\hline E. angolense & White tiama & $\begin{array}{l}\text { Decidous } \\
\text { (September- } \\
\text { November) }\end{array}$ & December & July-December & $\begin{array}{l}\text { Tylor, } 1960 ; \\
\text { Voorhoeve, } 1965\end{array}$ \\
\hline E. candollei & Kosipo & Decidous & November-December & May-August & Voorhoeve, 1965 \\
\hline E. cylindricum & Sapelli & Decidous & February-March & May-August & $\begin{array}{l}\text { Tylor, } 1960 ; \\
\text { Voorhoeve, } 1965\end{array}$ \\
\hline E. utile & Sipo & Decidous & January-February & December-March & Voorhoeve, 1965 \\
\hline
\end{tabular}


Table 4. Minimum Fruiting Diameter (MFD), Regular Fruiting Diameter (RFD) and Minimum Logging Diameter (MED) of Entandrophragma species - Diamètre minimum de fructification $(D M F)$, diamètre de fructification régulière (DFR) et diamètre minimum d'exploitation (DME) des essences d'Entandrophragma

\begin{tabular}{|c|c|c|c|c|c|c|}
\hline Species & Scientific name & MFD $(\mathrm{cm})$ & RFD $(\mathrm{cm})$ & MED $(\mathrm{cm})$ & Country & Reference \\
\hline \multirow[t]{9}{*}{ Kosipo } & E. candollei & 40 & & 80 & CAR & Yalibanda, 1999 \\
\hline & & & 85 & 70 & Ouganda & Plumptre, 1995 \\
\hline & & & & 110 & Ghana & Nyunaï, 2008 \\
\hline & & & & 90 & Liberia & \\
\hline & & & & 60 & $\mathrm{CI}$ & \\
\hline & & & & 80 & Gabon & \\
\hline & & & & & $\mathrm{RC}$ & \\
\hline & & & & & Cam & \\
\hline & & & & & DRC & \\
\hline \multirow[t]{11}{*}{ Sapelli } & E. cylindricum & & 75 & 80 & CAR & de Madron \& Daumeurie, 2004 \\
\hline & & & 85 & & Ouganda & Plumptre, 1995 \\
\hline & & 35 & & 80 & CAR & Petrucci et al., 1995 \\
\hline & & 55 & & 80 & CAR & Yalibanda, 1999 \\
\hline & & 40 & 55 & 90 & Gabon & Sépulchre et al., 2008 \\
\hline & & & & 60 & $\mathrm{CI}$ & Palla et al., 2012 \\
\hline & & & & 110 & Ghana & \\
\hline & & & & 90 & Liberia & \\
\hline & & & & 80 & $\mathrm{RC}$ & \\
\hline & & & & 100 & Cam & \\
\hline & & & & 80 & DRC & \\
\hline \multirow[t]{8}{*}{ Sipo } & E. utile & & 85 & 90 & Gabon & Sépulchre et al., 2008 \\
\hline & & & & 110 & Ghana & Mujuni, 2008 \\
\hline & & & & 100 & Cam & \\
\hline & & & & 90 & Liberia & \\
\hline & & & & 60 & $\mathrm{CI}$ & \\
\hline & & & & 80 & $\mathrm{RC}$ & \\
\hline & & & & 80 & DRC & \\
\hline & & & & 80 & CAR & \\
\hline \multirow[t]{10}{*}{ White tiama } & E. angolense & 55 & & 80 & CAR & Petrucci et al., 1995 \\
\hline & & 50 & & 80 & CAR & Yalibanda, 1999 \\
\hline & & & 85 & & Ouganda & Plumptre, 1995 \\
\hline & & & & 110 & Ghana & Tchinda, 2008 \\
\hline & & & & 90 & Liberia & \\
\hline & & & & 60 & $\mathrm{CI}$ & \\
\hline & & & & 80 & Gabon & \\
\hline & & & & 80 & $\mathrm{RC}$ & \\
\hline & & & & 80 & Cam & \\
\hline & & & & 80 & DRC & \\
\hline
\end{tabular}

« - »: no information - pas d'information; RC: Republic of Congo - République du Congo; Cam: Cameroon - Cameroun; DRC: Democratic Republic of Congo - République Démocratique du Congo; CAR: Central African Republic - République centrafricaine; CI: Côte d'Ivoire. 
in five woody valves. These fruits contain single-winged seeds that disperse by swirling in the wind (Louis \& Fouarge, 1947). Almost all seeds of the fruits are of the "heavy glider" type and usually fall in the immediate vicinity of the seed trees (Medjibe \& Hall, 2002). However, the dispersal of Entandrophragma samaras should be checked by additional dispersal measures (identification of installed seedlings). Indeed, a recent study based on molecular methods shows that wind dispersal of these samaras is greater than previously thought ( $\pm 600 \mathrm{~m})$ (Monthe et al., 2017a). This study also shows that samaras that are close to the mother foot due to low dispersion may be subject to higher predation. The latter is caused by annoying insects, e.g. Hypsipyla (de la Mensbruge, 1966; Poorter et al., 2004), rodents and/or ungulates (Poorter et al., 2004) attracted by the high oil content of Entandrophragma seeds (Louis \& Fouarge, 1947).

Natural regeneration. The low germination capacity of Entandrophragma seeds (de la Mensbruge, 1966), their predation (Louis \& Fouarge, 1947; de la Mensbruge, 1966), a somewhat unpredictable fruiting time in a year (Hall, 2011), a flowering that seems rhythmically supra-annual with years of better fruiting (Gillet et al., 2008) are all reasons why it is rare to encounter abundant natural regeneration of Entandrophragma. This rarity of natural regeneration varies from one Entandrophragma species to another, but is almost general to all species of the genus (Lemmens, 2008).

Population structure. The distribution curve of the population by diameter class is an indicator of the population structure and the level of regeneration. Population structure with a decreasing exponential curve indicates good regeneration, while a bell curve indicates poor regeneration. Between these two extremes, there are many intermediate curves whose interpretation is often delicate, notably due to the history of the forest and the accuracy of the inventory (Daïnou \& Doucet, 2010). Several preparatory studies for the drafting of management plans (FRM, 2007; FRM, 2009; Nature+, 2011) show that the structure of Entandrophragma species populations varies according to the degree of natural regeneration, the density, numbers and volumes of stems inventoried and the ecological conditions of each species. The structure of sapelli populations, for example, is generally an exponential decreasing curve or a linear decreasing curve, with a peak in the intermediate classes where young stems are better represented (generally in the undergrowth waiting for the canopy to open up so that they can develop). Regeneration is therefore not in deficit (FRM, 2007; FRM, 2009; Eckebil et al., 2017). In order to stabilize the exploitable population of this species, it would be necessary to limit sampling rates or extend the rotation period (Karsenty \& Gourlet-Fleury, 2006; Eckebil et al., 2017). The population structure of kosipo, sipo and white tiama is variable and their distribution curves are generally not characteristic. Thus, the exploitation of each of these species requires particular attention. Many measures must be taken (major recommendations) in order to guarantee their maintenance. These measures include increasing the minimum management diameter (MMD) or limiting exploitation coefficients, providing regeneration aid and even prohibiting their exploitation in certain plots or management series (Daïnou \& Doucet, 2010).

\section{CONCLUSIONS AND OUTLOOK}

The present review shows that the taxonomy of the genus Entandrophragma has undergone a major evolution since this generic name was proposed in 1894 by Casimir de Candolle. Nevertheless, some uncertainties remain about the delimitation of the species, in particular E. congoense which has been made synonymous with $E$. angolense by some authors, whereas it is recognized as a species in its own right by others. This problem could be solved, in particular using molecular genetic tools. Knowledge of the ecology and genetics of Entandrophragma species remains equally insufficient and deserves to be deepened. Thus, future research could focus in particular on:

- updating the geographical distribution of each species;

- molecular phylogeny likely to understand the distribution patterns of species within the genus;

- detailed knowledge of the temperament of each species by quantifying the diameters of the vessels from the marrow to the bark of the wood;

- detailed knowledge of the phenology of each species, taking into account the diversity of habitats and climate variations throughout the genus' range;

- the improvement of techniques to promote natural regeneration;

- the improvement of knowledge on the dissemination and fruiting of the species.

These new scientific investigations will contribute to improving the sustainability of Entandrophrogma species.

\section{Acknowledgements}

We would like to thank the "FCCC" and "FORETS" projects, financed by the European Union and implemented at the University of Kisangani by CIFOR in collaboration with R\&SD, for the doctoral scholarship, and at the Royal Museum of Central Africa for the "ABIC" scientific 
internship scholarship (2016 and 2017), to the "Centre de Recherche" in Yangambi from the "Institut National pour l'Étude et la Recherche Agronomique" (INERA) for regular access to its central library, to Jean-Yves de Vleeschouwer ("Laboratoire de Foresterie des Régions tropicales et subtropicales, Université de Liège-Gembloux Agro-Bio Tech") for the provision of relevant documentation. We would like to thank all those who supported us in the research and compilation of information related to this publication. Thanks also to the Congregation of the Priests of the Sacred Heart of Jesus for the meditative space granted during our various working stays at the "Scolasticat Père Déhon" in Kisangani and the "Communauté de Lemba" in Kinshasa (DRC).

\section{Bibliography}

Beeckman H., 2016. Wood anatomy and trait-based ecology. IAWA J., 37, 127-151, doi.org/10.1163/2294193220160127

Biwolé A.B., Bourland N., Daïnou K. \& Doucet J.-L., 2012. Définition du profil écologique de l'azobé, Lophira alata, une espèce ligneuse africaine de grande importance: synthèse bibliographique et perspectives pour des recherches futures. Biotechnol. Agron. Soc. Environ., 16, 217-228.

Burrows J., Schmidt E., Burrows S. \& Lötter M., 2017. Trees \& shrubs of Mozambique. Johannesburg, South Africa: Jacana Publishers.

Chevallier M.-H. et al., 2010. Les genres Entandrophragma (Meliaceae) et Dacryodes (Burseraceae) en Afrique centrale atlantique. In: Actes du colloque final de restitution du projet IFORA, Agropolis International, 21-22 juin 2010, Montpellier, France.

CJBG (Conservatoire et Jardin botaniques de la Ville de Genève), 2012. Base de données des plantes d'Afrique. Genève, Suisse : CJBG.

Daïnou K. \& Doucet J.-L., 2010. Évaluation de l'aménagement et de l'état des populations des essences exploitées par le Groupe SEFAC. Wavre, Belgique: Nature + .

de Candolle C., 1894. Meliaceae Novae. Bull. Herb. Boissier, II(9), 583-584.

de la Mensbruge G., 1966. La germination et les plantules des essences arborées de la forêt dense humide de la Côte d'Ivoire. Nogent-sur-Marne, France: Centre Technique Forestier Tropical.

de Wilde H.J.E., 2015. Meliaceae. In : Sosef S.M., Florence J., Banak L.N. \& Bourobou H.P., éds. Flore du Gabon. 47 : Aloaceae, Meliaceae, Rhizophoraceae. Leiden, Germany : Margraf Publishers, Weikersheim Backhuys Publishers.

Dikumbwa N., 1990. Facteurs écoclimatiques et sur les cycles biogéochimiques en forêt dense sèche zambézienne (Muhulu) du Shaba méridional. Géo-ÉcoTrop, 14, 1-159.
Doucet J.-L., 2003. L'alliance délicate de la gestion forestière et de la biodiversité dans les forêts du centre $d u$ Gabon. Thèse de doctorat: Faculté universitaire des Sciences agronomiques de Gembloux (Belgique).

Doucet J.-L. et al., 2016. Enrichment of Central African logged forests with high-value tree species: testing a new approach to regenerating degraded forests. Int. J. Biodivers. Sci. Ecosyst. Serv. Manage., 12(1-2), 83-95, doi.org/10.1080/21513732.2016.1168868

Doumenge C. et al., 2010. Évaluation des niches climatiques de quatre espèces d'Entandrophragma (Meliaceae) d'Afrique occidentale et centrale. Implications évolutives et paléoclimatiques. In : Actes du $19^{e}$ Congrès AETFAT, 25-30 avril 2010, Madagascar. Meise, Belgique: National Botanic Garden of Belgium.

Durrieu de Madron L., Favrichon V. \& Dupuy B., 1998. Croissance et productivité en forêt dense humide : bilan des expérimentations dans le dispositif de Mopri-Côte d'Ivoire (1978-1992). Montpellier, France : Cirad-Forêt.

Durrieu de Madron L. \& Daumerie A., 2004. Diamètre de fructification de quelques essences en forêt naturelle centrafricaine. Bois For. Trop., 281(3), 87-95.

Eckebil P.P.T. et al., 2017. Entandrophragma cylindricum (Sprague) Sprague (Meliaceae), une espèce ligneuse concurrentielle en Afrique centrale (synthèse bibliographique). Biotechnol. Agron. Soc. Environ., 21, 80-97.

FAO, 2011. La situation des forêts dans le bassin amazonien, le bassin du Congo et l'Asie du Sud-Est. Rapport préparé pour le sommet des trois bassins forestiers tropicaux du 31 mai au 3 juin 2011 à Brazzaville, République du Congo. Rome : FAO, OIBT.

Fayolle A. et al., 2015. Differential performance between two timber species in forest logging gaps and in plantations in Central Africa. Forests, 6, 380-394, doi. org/10.3390/f6020380

FRM (Forêt Ressources Management), 2007. Plan d'aménagement des unités forestières: 09-003, 09004a, 09-005a et 09-005b-SFID. Montpellier, France : FRM.

FRM (Forêt Ressources Management), 2009. Plan d'aménagement des unités forestières : 09-007 et 09008-SFID. Montpellier, France : FRM.

Garcia F., Noyer J.-L., Risterucci A.-M.\& Chevallier M.-H., 2004. Genotyping of mature trees of Entandrophragma cylindricum with microsatellites. J. Heredity, 95, 454457, doi.org/10.1093/jhered/esh071

Gillet J.-F., Ngalouo B. \& Missamba-Lola A.P., 2008. Rapport d'analyse - volet dynamique forestière. Projet CIB FFEM «Suivi du programme dynamique forestière - agroforesterie - inventaires faunes ". Brazzaville, République du Congo: Ministère de l'Économie Forestière.

Hall J.S., 2008. Seed and seedling survival of African mahogany (Entandrophragma spp.) in the Central African Republic: implications for forest management. 
For. Ecol. Manage., 255, 292-299, doi.org/10.1016/j. foreco.2007.09.050

Hall J.S., 2011. Natural forest silviculture for Central African Meliaceae. In: Günter S., Weber M., Stimm B. \& Mosandl R., eds. Silviculture in the tropics. Berlin: Springer.

Hall J.S., Harris D.J., Medjibe V. \& Ashton P.M.S., 2003. The effects of selective logging on forest structure and tree species composition in a Central African forest: implications for management of conservation areas. For. Ecol. Manage., 183, 249-264, doi.org/10.1016/s03781127(03)00107-5

Hall J.S., McKenna J.J., Ashton P.M.S. \& Gregoire T.G., 2004. Habitat characterizations understimate the role of edaphic factors controlling the distribution of Entandrophragma. For. Ecol. Manage., 85, 2171-2183, doi.org/10.1890/03-0043

Jolivet C. \& Degen B., 2012. Use of DNA fingerprints to control the origin of sapelli timber (Entandrophragma cylindricum) at the forest concession level in Cameroon. Forensic Sci. Int., 6, 487-493, doi.org/10.1016/j. fsigen.2011.11.002

Karsenty A. \& Gourlet-Fleury S., 2006. Assessing sustainability of logging practices in the Congo Basin's managed forests: the issue of commercial species recovery. Ecol. Soc., 11, 26, doi.org/10.5751/es-01668110126

Kenfack D., 2011. Resurrection in Carapa (Meliaceae): a reassessment of morphological variation and species boundaries using multivariate methods in a phylogenetic context. Bot. J. Linn. Soc., 165, 186-221, doi. org/10.1111/j.1095-8339.2010.01104.x

Koenen E.J., Clarkson J.J., Pennington T.D. \& Chatrou L.W., 2015. Recently evolved diversity and convergent radiations of rainforest mahoganies (Meliaceae) shed new light on the origins of rainforest hyperdiversity. New Phytol., 207(2), 327-339, doi. org/10.1111/nph.13490

Lemmens R.H.M.J., 2008. Entandrophragma excelsum (Dawe \& Sprague) Sprague. In: Louppe D., OtengAmoako A.A. \& Brink M., eds. Prota 7(1): Timbers/ Bois d'ouvre 1. Wageningen, The Netherlands: Prota.

Louis J. \& Fouarge J., 1947. Essences forestières et bois du Congo. 4 : Entandrophragma palustre. Bruxelles : Institut National pour l'Étude Agronomique du Congo belge (INEAC).

Lourmas M. et al., 2007. Reduced density due to logging and its consequences on mating system and pollen flow in the African mahogany Entandrophragma cylindricum. Heredity, 99, 151-160, doi.org/10.1038/sj.hdy.6800976

Makana J.-R.\& Thomas S.C., 2004. Dispersal limits natural recruitment of African mahoganies. Oikos, 106, 67-72, doi.org/10.1111/j.0030-1299.2004.13084.x

Malaisse F., 1993. The ecology of the Zambezian dry evergreen forest with recommendations for conservation management. In: Lieth H. \& Lohmann M., eds.
Restoration of tropical forest ecosystems. Dordrecht, The Netherlands: Kluwer Academic Press, 75-90.

Malaisse F., Dikumbwa N'L., Blancke V. \& Leteinturier B., 2000. Preliminary observations on Zambezian dry evergreen forest gaps. In: Ceulemans R., Bogaert J., Deckmyn G. \& Nijs I., eds. Topics in ecology: structure and function in plants and ecosystem. Antwerp, Belgium: University of Antwerp, 143-153.

Mangenot S. \& Mangenot G., 1962. Enquête sur les nombres chromosomiques dans une collection d'espèces tropicales. Bull. Soc. Bot. Fr., 109, 411-447, doi.org/10. 1080/00378941.1962.10838117

Medjibe V. \& Hall J.S., 2002. Seed dispersal and its implications for silviculture of African mahogony (Entandrophragma spp.) in undisturbed forest in the Central African Republic. For. Ecol. Manage., 170, 249257, doi.org/10.1016/s0378-1127(01)00769-1

Menga P., Bayol N., Nasi R. \& Fayolle A., 2012. Phénologie et diamètre de fructification du wengé, Millettia laurentii De Wild. : implications pour la gestion. Bois For. Trop., 312(2), 31-41, doi.org/10.19182/bft2012.312.a20501

Meunier Q., Moumbogou C. \& Doucet J.-L., 2015. Les arbres utiles $d u$ Gabon. Gembloux, Belgique: Les Presses agronomiques de Gembloux.

Monthe F. et al., 2017a. Extensive seed and pollen dispersal and assortative mating in the rain forest tree Entandrophragma cylindricum (Meliaceae) inferred from indirect and direct analyses. Mol. Ecol., 26(19), 5279-5291, doi.org/10.1111/mec.14241

Monthe F. et al., 2017b. Characterization of microsatellite markers in two African exploited trees, Entandrophragma candollei and E. utile (Meliaceae). Appl. Plant Sci., 5, 1600130, doi.org/10.3732/apps.1600130

Muellner A.N., Savolainen V., Samuel R. \& Chase M.W., 2006. The mahogany family "out-of-Africa": divergence time estimation, global biogeographic patterns inferred from plastid rbcL DNA sequences, extant, and fossil distribution of diversity. Mol. Phylogenet. Evol., 40, 236-250.

Muellner A.N., Pennington T.D. \& Chase M.W., 2009. Molecular phylogenetics of neotropical Cedreleae (mahogany family, Meliaceae) based on nuclear and plastid DNA sequences reveal multiple origins of "Cedrela odorata". Mol. Phylogenet. Evol., 52, 461-469, doi.org/10.1016/j.ympev.2009.03.025

Muellner A.N., Schaefer H. \& Lahaye R., 2011. Evaluation of candidate DNA barcoding loci for economically important timber species of the mahogany family (Meliaceae). Mol. Ecol. Resour., 11, 450-460, doi. org/10.1111/j.1755-0998.2011.02984.x

Mujuni D.B., 2008. Entandrophragma utile (Dawe \& Sprague) Sprague. In: Louppe D., Oteng-Amoako A.A. \& Brink M., eds. Prota 7(1): Timbers/Bois d'œuvre 1. Wageningen, The Netherlands: Prota.

Nature +, 2011. Révision de plan d'aménagement : unité forestière d'aménagement $n^{\circ} 09-021$ (Province du Sud- 
Arrondissement de Ma'an). Douala, Cameroun : Wijma Douala.

Nyunaï N., 2008. Entandrophragma candollei Harms. In: Louppe D., Oteng-Amoako A.A. \& Brink M., eds. Prota 7(1): Timbers/Bois d'œuvre 1. Wageningen, The Netherlands: Prota.

Onguene N.A. \& Kuyper T.W., 2001. Mycorrhizal associations in the rain forest of South Cameroon. For. Ecol. Manage., 140, 277-287.

Owona Ndongo P.-A. et al., 2009. Plantations de bois d'œuvre en zone équatoriale africaine : cas de l'arboretum de l'Enef de Mbalmayo au sud du Cameroun. Bois For. Trop., 299, 37-48, doi.org/10.19182/bft2009.299.a20421

Palla F., Louppe D. \& Forni E., 2002. Sapelli. Fiche technique, écologique et sylvicole. Montpellier, France : Cirad-Forêt.

Pennington T.D., Muellner A.N. \& Wise R., 2010. A monograph of Cedrela (Meliaceae). Milborne Port, UK: Dh Books.

Petrucci Y., Tandeau de Marsac G. \& Morel P.J., 1995. Évolution du peuplement adulte et de la régénération acquise après interventions sylvicoles. Dispositif de recherche en forêt dense de Boukoko-La Lolé. Appui à la recherche forestière Fac/Arf. Bangui, République centrafricaine : Ministère des Eaux, Forêts, Chasse et Pêche.

Plumptre A.J., 1995. The importance of "seed trees" for the natural regeneration of selectively logged tropical forest. Common For. Rev., 74, 253-258.

Poorter L., Bongers F., Kouamé F.Y.N. \& Hawthorne W.-D., 2004. Biodiversity of West African forests. An ecological atlas of woody plant species. Wallingford, UK: Cabi, doi.org/10.1079/9780851997346.0000

Roux J.P., 2003. Flora of South Africa. Cape Town: South African National Biodiversity Institute.

Sépulchre F., Daïnou K. \& Doucet J.-L., 2008. Étude de la vulnérabilité de 18 essences ligneuses commerciales d'Afrique centrale reprises sur la liste rouge de l'UICN. Gembloux, Belgique : Faculté universitaire des Sciences agronomiques de Gembloux.
Staner P., 1943. Les acajous du Congo Belge. Bull. Agric. Congo Belg., 34(1-2), 163-246.

Tailfer Y., 1989. La forêt dense d'Afrique Centrale. Identification pratique des principaux arbres. I. Approche forestière et morphologique. Wageningen, Pays-Bas : CTA.

Taylor C.J., 1960. Synecology and silviculture in Ghana. London: Thomas Nelson and Co.

Tchinda A.T., 2008. Entandrophragma angolense (Welw.) C.DC. In: Louppe D., Oteng-Amoako A.A. \& Brink M., eds. Prota 7(1): Timbers/Bois d'ouvre 1. Wageningen, The Netherlands: Prota.

The Plant List, 2013. Version 1.1, http://www.theplantlist. org/tpl1.1/search?q=Entandrophragma, (27 February 2018)

Voorhoeve A.G., 1965. Liberian high forest trees. A systematical botanical study of the 75 most important or frequent high forest trees, with reference to numerous related species. Wageningen, The Netherlands: Centre for Agricultural Publication and Documentation.

Welwitsch F., 1858. Apontamentos phyto-geographicos. Ann. Conselho Ultramarino, parte nâo official, Lisbonne, I, 526-580.

White F., 1986. La végétation de l'Afrique. Mémoire accompagnant la carte de végétation de l'Afrique. Paris : Orstom et Unesco.

Wilks C. \& Issembé Y., 2000. Guide pratique d'identification : les arbres de la Guinée Équatoriale, région continentale. Wetter, Allemagne : Curef.

Yalibanda Y., 1999. Phénologie en forêt dense de Ngotto (Rca). Bilan de trois années d'observation. In : Nasi R., Amsallem I. \& Drouineau S., éds. La gestion des forêts denses africaines aujourd'hui. Actes du séminaire Forafri de Libreville (Gabon), 12-16 octobre 1998, Montpellier, France. Montpellier, Cirad : France.

(67 ref.) 